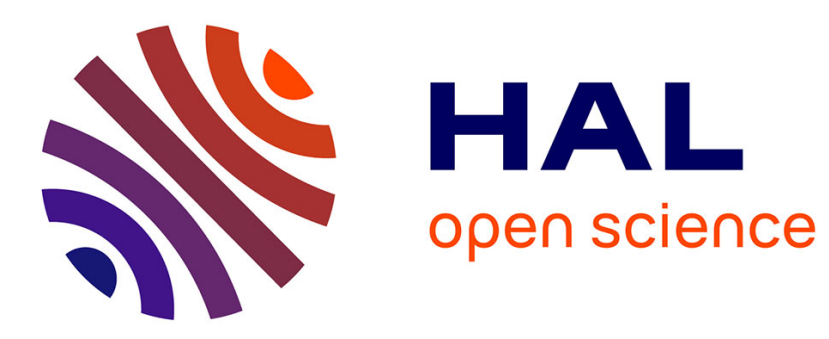

\title{
Azaindenocorannulenes: Synthesis, Properties, and Chirality
}

Xiaoqi Tian, Loïc M Roch, Nicolas Vanthuyne, Jun Xu, Kim K Baldridge, Jay

S Siegel

\section{- To cite this version:}

Xiaoqi Tian, Loïc M Roch, Nicolas Vanthuyne, Jun Xu, Kim K Baldridge, et al.. Azaindenocorannulenes: Synthesis, Properties, and Chirality. Organic Letters, 2019, 21 (10), pp.3510-3513. 10.1021/acs.orglett.9b00718 . hal-02514517

\section{HAL Id: hal-02514517 https://hal.science/hal-02514517}

Submitted on 23 Mar 2020

HAL is a multi-disciplinary open access archive for the deposit and dissemination of scientific research documents, whether they are published or not. The documents may come from teaching and research institutions in France or abroad, or from public or private research centers.
L'archive ouverte pluridisciplinaire HAL, est destinée au dépôt et à la diffusion de documents scientifiques de niveau recherche, publiés ou non, émanant des établissements d'enseignement et de recherche français ou étrangers, des laboratoires publics ou privés. 


\title{
Azaindenocorannulenes: Synthesis, Properties, and Chirality
}

Tian, X. Q.

Roch, L. M.

Vanthuyne, N.

$\mathrm{Xu}, \mathrm{J}$.

Baldridge, K. K.

Siegel, J. S.

\begin{abstract}
Palladium-catalyzed intramolecular arylation provides bowlshaped azaindenocorannulenes 7-9. Crystals of 8 show bowl-in-bowl columnar stacking. A substituent model rationalizes the first reduction potential of 18 related molecular bowls. The absolute configurations of bowls 7 and 9 are correlated with VCD and ECD spectra. The bowl inversion barrier of 9 (>190 $\mathrm{kJ} / \mathrm{mol}$ ) shows it to be more inert configurationally than chiral biaryl, phosphenes, or $[n]$ helicenes.
\end{abstract}

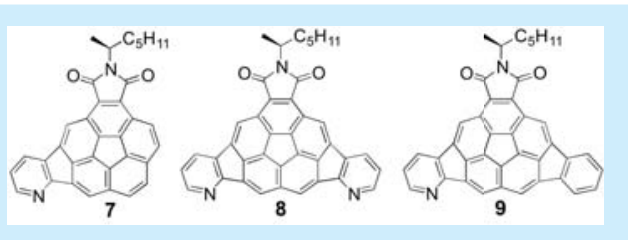

$\mathrm{R}$ ecent advances in the synthesis of indenocorannulenes enable the synthesis of pyridinoid bowls, with nitrogen replacing rim- $\mathrm{CH}$ groups of indenocorannulene. ${ }^{1}$ Introduction of heteroatoms into curved aromatic structures enables one to tailor the optoelectronic properties of the carbon bowl-shaped motifs. ${ }^{1-9}$ In particular, doping of nitrogen into the indole core analog of corannulene ${ }^{2,4}$ and the aza-sumanene series ${ }^{5}$ has shown to enable unique tuning of their electrochemical, photophysical, and bowl-dynamic properties (Figure 1).
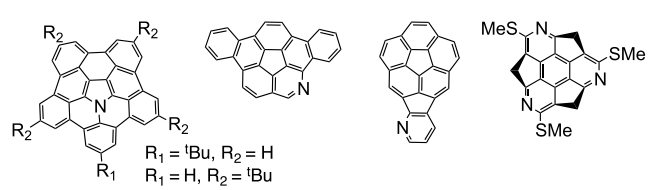

Figure 1. Representative aza-curved aromatic structures.

Resolution-epimerization studies of a chiral monoazadiindenocorannuleneimide 9 reveals that even simple chiral bowl derivatives can exceed the configurational stability of phosphines, $\mathbf{o}, \mathrm{o}^{\prime}, \mathrm{o}^{\prime \prime}, \mathrm{o}^{\prime \prime \prime}$-substituted biaryls, and extended helicenes, making higher order indenocorannulenes attractive targets for future studies of kinetically inert chiral scaffolds.

When screening conditions to optimize the palladium mediated coupling reaction of $\mathbf{2}^{10}$ with 2-chloropyridine-3boronicacid $(\mathrm{CPB})$, conditions were found to obtain the product as either a conveniently separable mixture of $2,3,4$, and $5[\mathrm{CPB}$ ( 4 equiv) $=>46: 1: 9: 44]$ or a mixture dominant in 4 [CPB (8 equiv) $=>0.0: 7.5: 92: 0.5]$ (Scheme 1$).{ }^{11-13}$ Reactions were repeated multiple times to establish gram-scale protocols where either 5 can be isolated in $40 \%$ yield, with recovery of an equal amount of 2, or 4 can be isolated in $80 \%$ yield, with complete conversion of 2 . Coupling of 5 with 2chlorophenylboronic acid gives asymmetric 6. Palladiumcatalyzed intramolecular ring closure of 3, 4, and 6 reproducibly produced 7,8 , and 9 in $30-45 \%$ yield. Typical

\section{Scheme 1}

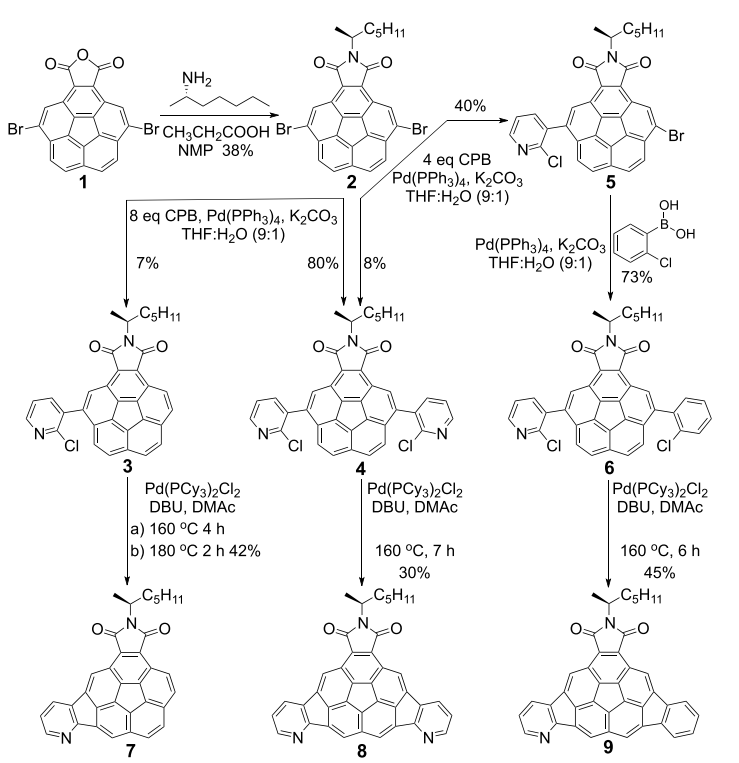

reports use microwave irradiation heating to accelerate this type of reaction; ${ }^{14,15}$ however, here oil bath heating gave robust results.

Crystals of $\mathbf{8}$ suitable for X-ray diffraction analysis have a triclinic $P 1$ space group, with four molecules in each unit cell (1892126, Figure 2). The crystal-packing diagram reveals a rough antiparallel columnar structure. The bowl depth of $\mathbf{8}$ is determined to be $1.175 \AA$ (calcd $1.221 \AA$ ), which is slightly less than its carbon analogue 21 at $1.189 \AA$ (calcd $1.223 \AA$ ).

Structure correlation over the electrochemical data of 18 compounds including 7-9 and previous studies ${ }^{10,14,16,17}$ 


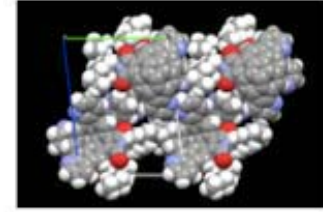

a

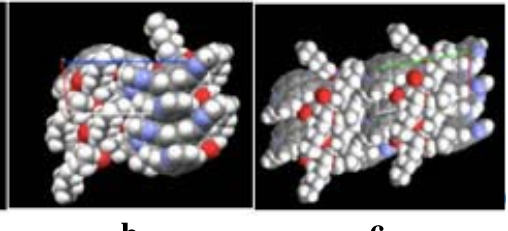

b

c
Figure 2. Crystal packing of 8 along a, b, and c axes, respectively.

reveals a tendency for imido-, aza-indeno-, and indenoannulations to lower the first reduction potential compared to $\mathbf{1 0}$ (Table 1, Figure 3). The variance in the data seems to

Table 1. $E_{\mathrm{c}}{ }^{*}(\mathrm{eV}), E_{1 / 2}(\mathrm{eV})$, and $I_{\mathrm{pa}} / I_{\mathrm{pc}}$ for 7,8 , and 9

\begin{tabular}{llcl} 
& \multicolumn{1}{c}{7} & \multicolumn{1}{c}{$\mathbf{8}$} & \multicolumn{1}{c}{$\mathbf{9}$} \\
$E_{\mathrm{c}}^{*}(\mathrm{eV})^{a}$ & $-1.62(-1.47)^{b}$ & $-1.48(-1.42)$ & $-1.53(-1.47)$ \\
$E_{1 / 2}(\mathrm{eV})$ & -1.53 & -1.42 & -1.46 \\
$I_{\mathrm{pa}} / I_{\mathrm{pc}}$ & 0.73 & 0.87 & 0.84
\end{tabular}

${ }^{a}$ Solvent: THF. Working electrode: glassy carbon. Reference electrode: $\mathrm{Ag} / \mathrm{Ag}^{+}$in acetonitrile. Counter electrode: platinum wire. Scan rate: $0.1 \mathrm{~V} \mathrm{~s}^{-1}$. Supporting electrolyte: tetrabutylammonium hexafluorophosphate $\left(\mathrm{TBAPF}_{6}\right) \cdot E_{\mathrm{c}}{ }^{*}=$ reduction potential. $E_{1 / 2}=$ half-wave potential. $I_{\mathrm{pa}}=$ peak anodic current. $I_{\mathrm{pc}}=$ peak cathodic current. ${ }^{b} \mathrm{~B} 97-\mathrm{D} / \mathrm{Def} 2-\mathrm{TZVPP}(\mathrm{THF})$ values in parentheses, using $E_{\mathrm{c}}{ }^{\circ}$ $=-\Delta H / n F-\mathrm{ref}_{\mathrm{Ag} / \mathrm{AgCl}}$, where $n=1, F=1 \mathrm{eV}$.

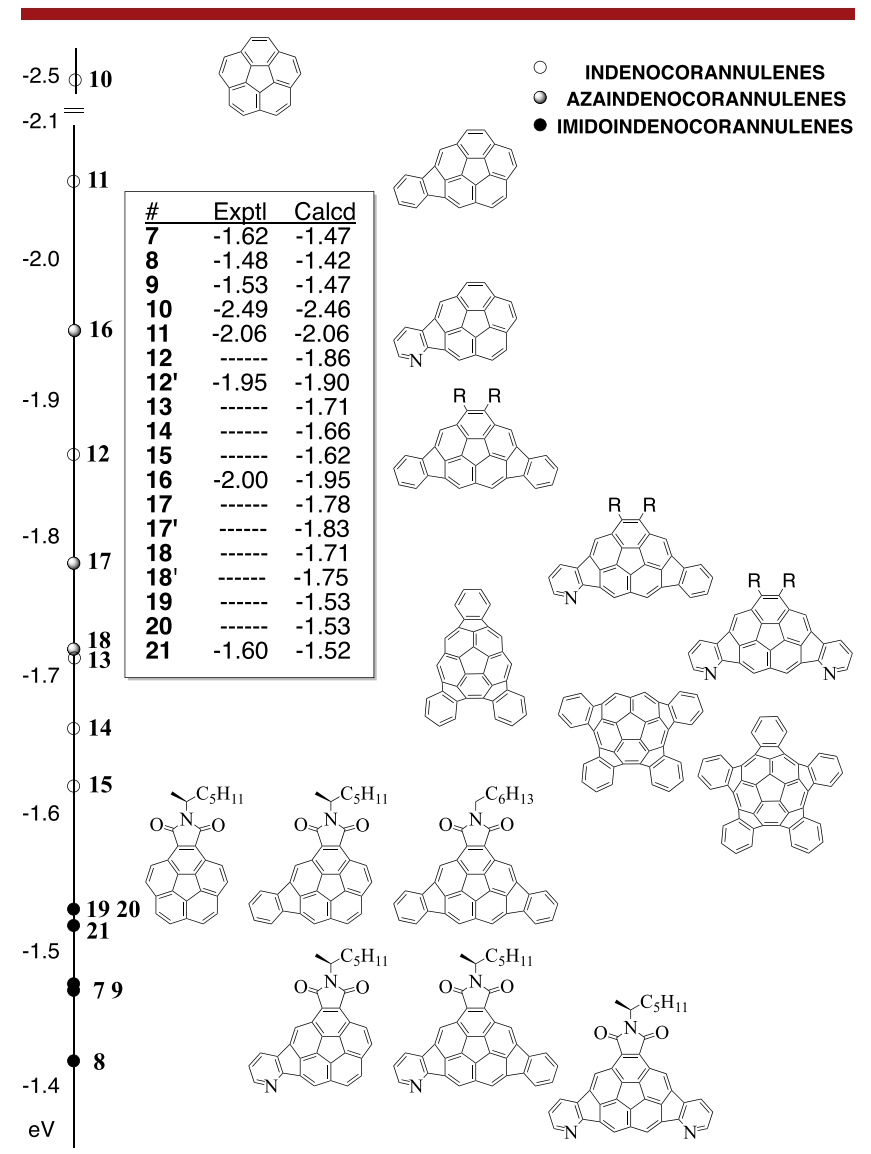

Figure 3. Experimental and B97-D/Def2-TZVPP(THF) first reduction potentials for $7-21 . \mathrm{R}=\mathrm{H}$, Me $\left(12,12^{\prime}, 17,17^{\prime}, 18,18^{\prime}\right)$.

come from three effects: (1) expansion of the $\pi$ orbital volume by additional benzene rings; (2) nitrogen atom doping; (3) stabilization by electron-withdrawing imide functionality.
Although expansion of the $\pi$-system has an initial effect of nearly $0.5 \mathrm{eV}$, it wanes to the point that the fifth ring lowers the potential by only $0.04 \mathrm{eV}$, a tenth of the effect of the first. Nitrogen doping has a more consistent effect of ca. 0.05-0.1 $\mathrm{eV} /$ nitrogen atom. Imide functionality appears to play the largest role in reducing the first reduction potential of the parent, nearly $1.0 \mathrm{eV}$. Bowl structure 8 , which combines imide functionality, two annulations, and two nitrogen atoms, yields the lowest reduction potential in this study at $-1.48 \mathrm{eV}$ (calcd $=-1.42$ ), placing its reduction potential closer to $\mathrm{C}_{60}$ at $-0.98^{18,19}$ (herein calcd -1.03) eV than to corannulene at -2.49 (calcd -2.46) eV.

Reduction potential values as a function of increasing number of indeno-annulations supports a saturation as opposed to an additive substituent effect (Figure 4). In a

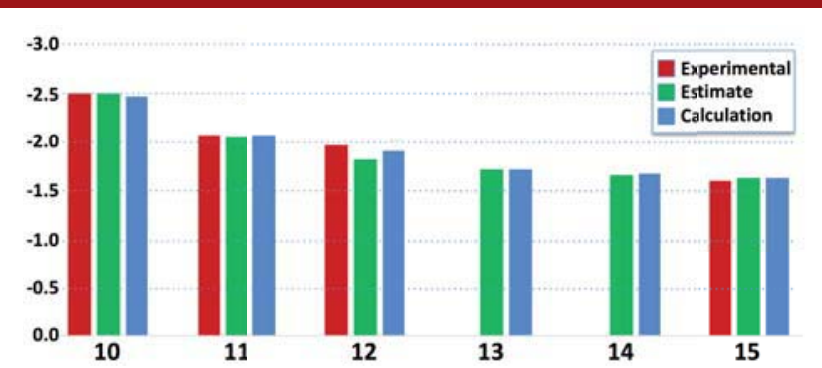

Figure 4. Experimental, regression estimate, and B97-D/TZVPP(THF) determined reduction potential data for 10-15.

simple saturation model there is a base substituent value $(S)$ and an attenuation factor. Assuming a base value for indeno annulation of $0.45 \mathrm{eV}$ and an attenuation factor of 0.5 reasonably rationalizes the series $\mathbf{1 0 - 1 5}$, as $E_{\text {(est) }}=-2.49+$ $\Sigma \mathrm{S}(0.5)^{n-1}, n=$ first to fifth substituent.

The strong influence of the imido group on corannulene has been seen previously. ${ }^{20}$ This perturbation also influences the effect of $\pi$-annulation, effectively limiting the distribution of the HOMO in the radical anion (Figure 5). Whereas simple
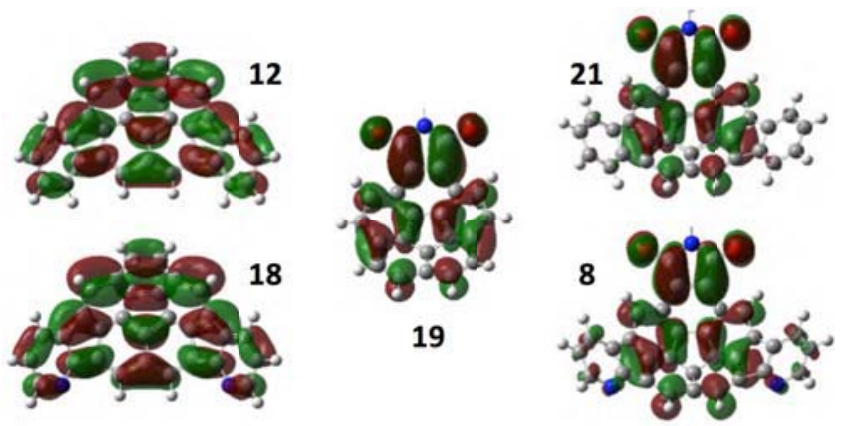

Figure 5. B97-D/Def2-TZVPP(THF) HOMO orbitals of select radical anions.

indenocorannulenes $\mathbf{1 2}$ and $\mathbf{1 8}$ show contributions from the whole $\pi$-volume, 21 shows almost no contribution from the indeno segments and also no change in reduction potential compared to 19. For 8 there appears a small contribution from the azaindeno segments and a small lowering of the reduction potential. These results highlight the importance of understanding the interaction among substituents when designing molecular properties, such as reduction potential-additive behavior cannot be assumed. 
In contrast to the electrochemical properties, the trends in photophysical properties are less dramatic (Figure 6, Table 2).

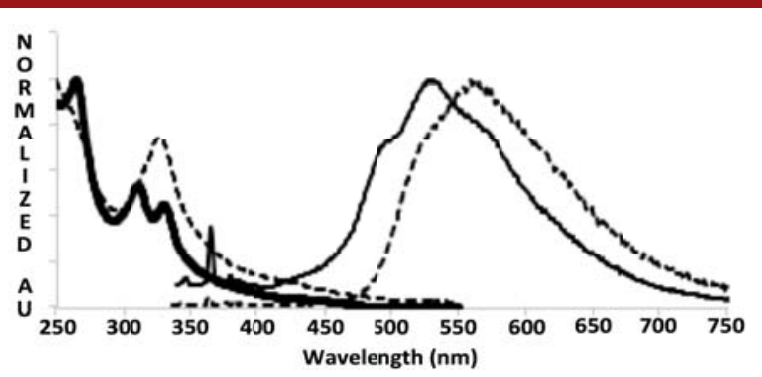

Figure 6. UV and fluorescence spectra of 7: (-) natural, (---) protonated (HOTf).

Table 2. Photophysical Properties of 7, 8, and 9

\begin{tabular}{lllllll} 
compd & $\tau(\mathrm{ns})$ & $\mathrm{X}^{2}$ & $\Phi(\%)$ & $\mathrm{Ex}(\mathrm{nm})$ & $\mathrm{Em}(\mathrm{nm})$ & \multicolumn{1}{c}{$\lambda_{\mathrm{abs}}(\mathrm{nm})$} \\
$\mathbf{7}^{a}$ & 5.61 & 1.20 & 1.55 & 329 & 529 & $264,310,329$ \\
$7-\mathrm{H}^{b}$ & $\mathrm{~N}$ & & 2.50 & 327 & 559 & 327 \\
$\mathbf{8}^{a}$ & 8.50 & 0.96 & 2.75 & 329 & 525,562 & 278,330 \\
$\mathbf{8}^{-} \mathrm{H}^{b}$ & $\mathrm{~N}$ & & 1.09 & 338 & 592 & $265,299,340$ \\
$\mathbf{9}^{a}$ & 7.27 & 1.05 & 3.49 & 332 & 528,563 & 274,332 \\
$\mathbf{9 - H}^{b}$ & $\mathrm{~N}$ & & 1.33 & 317 & 608 & $275,316,346$ \\
${ }^{a}$ Solvent is cyclohexane. & ${ }^{b}$ Solvent is dichloromethane.
\end{tabular}

An increase in the number of annulations correlates with an increase in the wavelength of absorption and emission for the hydrocarbon and aza-derivatives. Predictably, hydrocarbons tend to be insensitive to $\mathrm{pH}$ in normal ranges, whereas azacontaining derivatives undergo protonation that shifts the absorption and emission spectra to longer wavelengths (ca. $30-50 \mathrm{~nm}){ }^{21}$ Fluorescence quantum yields are generally thought to decrease with greater curvature, but the present data do not support this trend. Lifetime data for 7, 8, and 9 ranges from 5.61 to $8.50 \mathrm{~ns}$, only a slightly larger variance than that seen previously for diindenocorannulenes $\mathbf{1 2}$ and $21 .^{10}$

Enantiomeric resolution of indenocorannulenes allows investigation of bowl inversion barriers by racemization studies. ${ }^{1}$ Racemization of monoaza-indenocorannulene 16 shows that replacement of $\mathrm{CH}$ by $\mathrm{N}$ results in only a minor perturbation. As such, chiral monoaza-diindenocorannuleneimide 9 should display a bowl inversion barrier representative of dindenocorannulenes in general. Two diastereomers in a 1:1 ratio were found for 7 and 9, with different bowl configurations. The chiroptical properties are mainly due to the bowl shape rather than the stereogenic carbon.

Preparative HPLC of 9 over Chiralpak IF resolved the diastereomers. HPLC analysis of timed-sequenced aliquots of 9 (diphenyl ether @218 ${ }^{\circ} \mathrm{C}$ ) revealed a half-life of thousands of hours, which for a first-order asymmetric transformation correlates to a remarkable barrier of $192 \pm 5 \mathrm{~kJ} / \mathrm{mol}$ (Table 3). B97-D/Def2-TZVP(diphenylether) calculations predict a barrier of $199 \mathrm{~kJ} / \mathrm{mol}$, in good agreement with the

Table 3. Bowl-Inversion Parameters of 7 and 9

$\begin{array}{cccccc}\text { compd } & k\left(\mathrm{~s}^{-1}\right) & t_{1 / 2}(\mathrm{~h}) & \Delta G\left(\mathrm{~kJ} \mathrm{~mol}^{-1}\right) & \mathrm{calcd}^{a} & T(\mathrm{~K}) \\ 7 & 2.84 \times 10^{-5} & 3.4 & 111.6 & 108.1 & 335 \\ 9 & 3.84 \times 10^{-8} & 2509 & 192 \pm 5 & 199.6 & 491\end{array}$

${ }^{a}$ B97-D/Def2-TZVP $\left(\mathrm{CHCl}_{3}\right)$ (7), B97-D/Def2-TZVP $\left(\left(\mathrm{C}_{6} \mathrm{H}_{5}\right)_{2} \mathrm{O}\right)$

(9), with the same solvent choice as in the experiment. experimental value. This bowl-inversion barrier exceeds that found for triazasumanene (ca. $180 \mathrm{~kJ} / \mathrm{mol}$ ), ${ }^{5}$ another remarkably rigid bowl-shaped molecule. This barrier also exceeds the barrier to rotation in $1,1^{\prime}$-binaphthalene-2,2' -diol (ca. $160 \mathrm{~kJ} / \mathrm{mol}){ }^{22,23}$ the barrier to inversion in triarylphosphines $(150 \mathrm{~kJ} / \mathrm{mol}){ }^{24,25}$ and the formation enthalpy for most coordinative-covalent bonds $(<150 \mathrm{~kJ} / \mathrm{mol}){ }^{26}$ It is on the order of weak covalent bonds, such as the carbon-iodine bond (ca. $210-240 \mathrm{~kJ} / \mathrm{mol}$ ). ${ }^{27}$ Thus, atropisomeric ${ }^{28,29}$ bowl 9 can be as configurationally inert as many classical tetrahedral stereocenters.

As carbon sheets in general are not rigid constructs, they may not be considered as the best medium for building chiral scaffolds. Warping graphenes by several tens of degrees costs less than $50 \mathrm{~kJ} / \mathrm{mol}^{30}$ Twisted acenes with twist angles well over $90^{\circ}$ still rapidly racemize in solution..$^{31,32}$

$[n]$ Helicenes $(n>5)$ represent the classic series of chiral carbon ribbons that display barriers to racemization sufficient to allow resolution; however, their barriers to racemization show a plateau effect around $180 \mathrm{~kJ} / \mathrm{mol}$ for [10] helicene and higher homologues. ${ }^{33-35}$ In contrast, indenocorannulene bowlinversion barriers are predicted to exceed even $\mathrm{C}-\mathrm{C}$ covalent bond-formation energies. With increasing efficiencies in the synthesis of bowl-shaped aromatics, bowls are well poised to be the next major chiral scaffolds for chiral materials and catalysts.

Configurational assignments for these chiral structures can be made by comparison of the experimental vibrational and electronic circular dichroism spectra (VCD and ECD, respectively) with their quantum mechanically predicted spectra (Figure 7). The VCD of 7 and 9 were measured

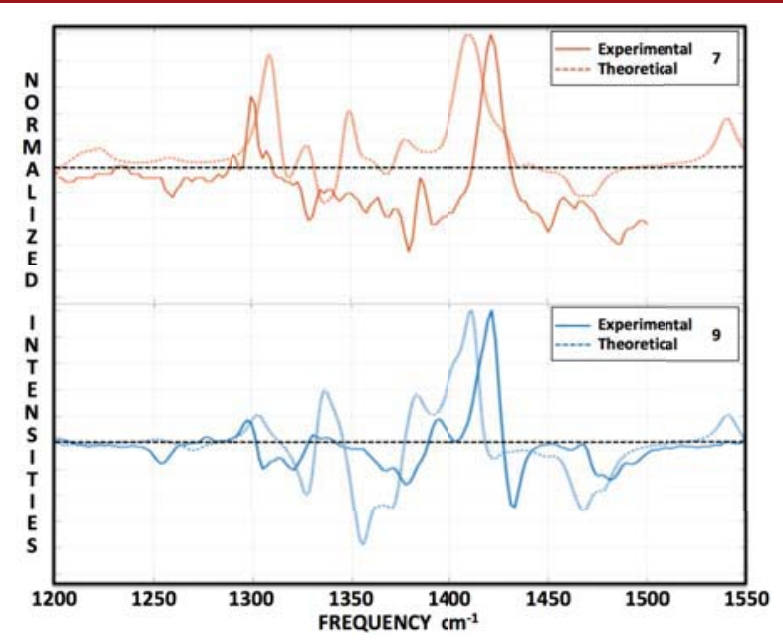

Figure 7. Experimental (-) and wB97X-D/Def2-TZVPP $\left(\mathrm{CHBr}_{3}\right)$ (---) VCD spectra of 7 (top, red) and 9 (bottom, blue), expt first eluted.

$\left(\mathrm{CHBr}_{3}\right)$ and compared to wB97x-D/Def2-TZVPP $\left(\mathrm{CHBr}_{3}\right)$ determined spectra. The rigid character of these nanometersized scaffolds facilitates the quantum mechanical analysis by restricting the conformational diversity. Comparison of the regions of the spectra $1200-1550 \mathrm{~cm}^{-1}$ enabled configurational assignment.

The ECD spectra of 7 and 9 were also measured $\left(\mathrm{CH}_{3} \mathrm{CN}\right)$ and compared to TD-camB3LYP/Def2-TZVPP $\left(\mathrm{CH}_{3} \mathrm{CN}\right)$ determined spectra. Assignments by VCD were corroborated by comparison of experimental and computed ECD spectra; see Supporting Information. 
Palladium-mediated intramolecular arylation facilitates the synthesis of three new aza-indenocorannulenes 7-9. A model to rationalize the first reduction potentials for 18 related molecular bowls reveals $\pi$-volume, $\mathrm{N}$ atom doping, and fragment orbital overlap as important factors in the design of electron-acceptor bowls. Diastereomers of 7 and 9 were resolved by chromatography over chiral stationary phase, and their absolute configurations were asserted by comparison of their experimental and computationally predicted VCD and ECD spectra. Epimerization studies revealed a barrier to bowl inversion for 7 and 9 of 111.6 and $192 \mathrm{~kJ} / \mathrm{mol}$, respectively; the bowl inversion barrier of 9 is the largest yet reported for corannulene derivatives. The nanometer dimensions and robust configurational character of these scaffolds make them ideal candidates for use in the general design of chiral materials and scaffolds for new chiral catalysts for stereoselective synthesis.
(3) Tsefrikas, V. M.; Greene, A. K.; Scott, L. Org. Chem. Front. 2017, 4, 688-698.

(4) Ito, S.; Tokimaru, Y.; Nozaki, K. Angew. Chem., Int. Ed. 2015, 54, $7256-7260$.

(5) Tan, Q.; Higashibayashi, S.; Karanjit, S.; Sakurai, H. Nat. Commun. 2012, 3, 891.

(6) Dix, I.; Doll, C.; Hopf, H.; Jones, P. G. Eur. J. Org. Chem. 2002, 2002, 2547-2556.

(7) Imamura, K.; Takimiya, K.; Yoshio, A.; Otsubo, T. Chem. Commun. 1999, 1859-1860.

(8) Furukawa, S.; Kobayashi, J.; Kawashima, T. J. Am. Chem. Soc. 2009, 131, 14192-14193.

(9) Saito, M.; Tanikawa, T.; Tajima, T.; Guo, J.; Nagase, S. Tetrahedron Lett. 2010, 51, 672-675.

(10) Tian, X.; Roch, L. M.; Baldridge, K. K.; Siegel, J. S. Eur. J. Org. Chem. 2017, 2017, 2801-2805.

(11) Smith, A. E.; Clapham, K. M.; Batsanov, A. S.; Bryce, M. R.; Tarbit, B. Eur. J. Org. Chem. 2008, 2008, 1458-1463.

(12) Miyaura, N.; Suzuki, A. Chem. Rev. 1995, 95, 2457-2483.

(13) Bouillon, A.; Lancelot, J.-C.; Collot, V.; Bovy, P. R.; Rault, S. Tetrahedron 2002, 58, 2885-2890.

(14) Steinberg, B. D.; Jackson, E. A.; Filatov, A. S.; Wakamiya, A.; Petrukhina, M. A.; Scott, L. T. J. Am. Chem. Soc. 2009, 131, 1053710545.

(15) Jackson, E. A.; Steinberg, B. D.; Bancu, M.; Wakamiya, A.; Scott, L. T. J. Am. Chem. Soc. 2007, 129, 484-485.

(16) Lampart, S.; Roch, L. M.; Dutta, A. K.; Wang, Y.; Warshamanage, R.; Finke, A. D.; Linden, A.; Baldridge, K. K.; Siegel, J. S. Angew. Chem., Int. Ed. 2016, 55, 14648-14652.

(17) Dutta, A. K.; Linden, A.; Zoppi, L.; Baldridge, K. K.; Siegel, J. S. Angew. Chem., Int. Ed. 2015, 54, 10792-10796.

(18) Yanilkin, V. V.; Gubskaya, V. P.; Morozov, V. I.; Nastapova, N. V.; Zverev, V. V.; Berdnikov, E. A.; Nuretdinov, I. A. Russ. J. Electrochem. 2003, 39, 1147-1165.

(19) Green, W. H.; Gorun, S. M.; Fitzgerald, G.; Fowler, P. W.; Ceulemans, A.; Titeca, B. C. J. Phys. Chem. 1996, 100, 14892-14898.

(20) Schmidt, B. M.; Topolinski, B.; Roesch, P.; Lentz, D. Chem. Commun. 2012, 48, 6520-6522.

(21) Zhang, J.; Chen, J.; Xu, B.; Wang, L.; Ma, S.; Dong, Y.; Li, B.; Ye, L.; Tian, W. Chem. Commun. 2013, 49, 3878-3880.

(22) Meca, L.; Reha, D.; Havlas, Z. J. Org. Chem. 2003, 68, 56775680.

(23) Kyba, E. P.; Gokel, G. W.; De Jong, F. D.; Koga, K.; Sousa, L. R.; Siegel, M. G.; Kaplan, L.; Sogah, G. D. Y.; Cram, D. J. J. Org. Chem. 1977, 42, 4173-4184.

(24) Sasaki, S.; Yoshifuji, M. Curr. Org. Chem. 2007, 11, 17-31.

(25) Holz, J.; Jiao, H.; Gandelman, M.; Börner, A. Eur. J. Org. Chem. 2018, 2018, 2984-2994.

(26) Lepetit, C.; Maraval, V.; Canac, Y.; Chauvin, R. Coord. Chem. Rev. 2016, 308, 59-75.

(27) Blanksby, S. J.; Ellison, G. B. Acc. Chem. Res. 2003, 36, 255263.

(28) Siegel, J. S. Synlett 2018, 29, 2120-2121.

(29) Siegel, J. S. Synlett 2018, 29, 2122-2125.

(30) Wolf, E. L. Graphene: A New Paradigm in Condensed Matter and Device Physics; Oxford University Press: New York, NY, USA, 2013.

(31) Gidron, O.; Shimon, L. J. W.; Bedi, A. J. Am. Chem. Soc. 2018, 140, 8086-8090.

(32) Pascal, R. A., Jr. Chem. Rev. 2006, 106, 4809-4819.

(33) Ravat, P.; Hinkelmann, R.; Steinebrunner, D.; Prescimone, A.; Bodoky, I.; Jerîcek, M. Org. Lett. 2017, 19, 3707-3710.

(34) Martin, R. H.; Marchant, M. J. Tetrahedron Lett. 1972, 13, 3707-3708.

(35) Janke, R. H.; Haufe, G.; Würthwein, E. U.; Borkent, J. H. J. Am. Chem. Soc. 1996, 118, 6031-6035.
(1) Wang, Y.; Allemann, O.; Balaban, T. S.; Vanthuyne, N.; Linden, A.; Baldridge, K. K.; Siegel, J. S. Angew. Chem., Int. Ed. 2018, 57, 6470-6474.

(2) Yokoi, H.; Hiraoka, Y.; Hiroto, S.; Sakamaki, D.; Seki, S. Nat. Commun. 2015, 6, 8215 . 